811.163.41'367.625

https://doi.org/10.18485/msc.2018.47.3.ch8

\author{
Балша Н. СТИПЧЕВИЋ ${ }^{*}$ \\ Филолошки факултет \\ Универзитета у Београду
}

\title{
ШТА СУ ТО БЕЗЛИЧНИ ГЛАГОЛИ?
}

\begin{abstract}
У раду се испитује појам безличног глагола у домаћој граматичкој литератури, с освртом и на домаћу лексикографску праксу. Разматрају се и коментаришу различити начини и критеријуми њиховог дефинисања.
\end{abstract}

Кључне речи: синтакса, семантика, српски језик, безличност, безлични глаголи, имперсонални глаголи

1. Предмет овог рада јесу БЕзлични (имПЕРСОНАлни) глАГоли. Циљ нам је да сагледамо како се овај термин, појам и категорија третирају у граматичкој литератури, да размотримо проблеме који се у вези њима могу јавити, те да се определимо за концепцију која нам се чини најмање проблематична. Тема, мислимо, нема само теоријски значај, већ је важна како за лексикографску, тако и за наставну праксу.

2.1. Термин и појам којим се бавимо заснива се на једној од могућих подела глагола. Сама та подела је врло стара: можемо је наћи још у Вуковој Писменици, где стоји да лични глагол ,јест онај, који сва три лица у јединственом, и у множественом броју има”, а безлични глагол ,јест онај који се само с трећим лицем у јединственом броју спреже", што се илуструје глаголима грмети, догодити се, наоблачити се и болети (КАРАџи 1814: 49), као и требати (idem: 101). Сличну формулацију Вук ће дати и у Граматици уз Рјечник, али уз опаску да „ово задјеленије глагола не вриједи готово ништа”, jep, прво - „млоги глаголи, који се броје у безличне, могу имати и остала лица”, и друго - „макар имали и једно лице, опет нијесу безлични, него лични" (КАРАџИЋ 1818: LV). Можемо претпоставити да је ову поделу, у вези с којом, како видимо, има знатне резерве, Вук преузео, директно или индиректно, из граматографске традиције латинског језика, која је у то време свакако важила као неприкосновени узор. ${ }^{1}$ И док другу Вукову замерку данас лако

\footnotetext{
*balsa@fil.bg.ac.rs.

${ }^{1}$ У бројним школским латинским граматикама 19. века могу се прочитати дефиниције попут ове: „Глаголи су или лични или безлични. Лични глагол је онај који допушта личне заменице
} 
можемо оставити по страни, будући да имамо на располагању термине одн. појмове Финитни и инФинитни глАголски оБлик, прва његова замерка и даље се може сматрати актуелном.

2.2. Већина граматичких приручника ову ће поделу у извесној мери занемарити, па личне глаголе неће помињати као термин и појам, а дотицаће се искључиво безличних глагола. Ово није тешко разумети, па ни оправдати, с обзиром на то да је подела изузетно асиметрична: личних је неупоредиво више од безличних и чине немаркиран члан опозиције, што их чини одвећ „обичним” и „незанимљивим” да би били посебно терминолошки-појмовно издвојени. ${ }^{2}$ Следећом табелом покушаћемо сажето да представимо да ли је, и како, овај термин и појам третиран у одабраним граматичким приручницима. ${ }^{3}$

\begin{tabular}{|c|c|}
\hline ПРИРУЧНИК & ДЕФИНИЦИЈА \\
\hline МАРЕТИЋ ${ }^{3} 1963$ & [Не помиње безличне глаголе.] \\
\hline БЕЛЙ 1933/2000 & $\begin{array}{l}\text { Има глагола који немају ни субјекта ни објекта; у који- } \\
\text { ма се износи само да се једна радња врши, да она бива } \\
\text { или се дешава. На пр. Или грми ил' се земља тресе. } \\
\text { - Свағује. - Мрзне се. Кад јако загрми, ја се уплашим. } \\
{[\ldots . .]} \\
\text { У овим реченицама: грми значи трајну радњу, за коју } \\
\text { се зна да бива, али се не зна ко је врши; то је, дакле, } \\
\text { безлична радња, трајна и непрелазна. [...] } \\
\text { Глаголи који показују да радња бива, али не зна се ко је } \\
\text { врши, називају се глаголима за бивање. (186) }\end{array}$ \\
\hline БРАБЕЦ et al. ${ }^{2} 1954$ & $\begin{array}{l}\text { Говорећи о неким појавама, не мислимо, тко радњу } \\
\text { врши. У таквим реченицама не може онда ни бити } \\
\text { субјекта. У њима није субјект неизречен, него га уопће } \\
\text { нема. У њима је глагол у трећем лицу једнине. Такав } \\
\text { глагол зове се безличан: Грми. Свиће. Говори се. (183) }\end{array}$ \\
\hline СтЕвовИћ 1960 & 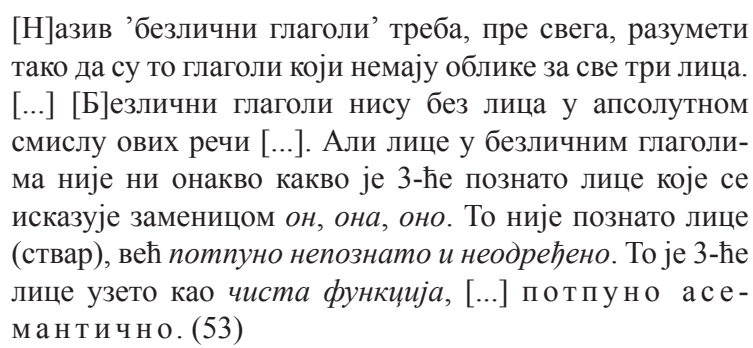 \\
\hline
\end{tabular}

ego, ja; tu, ти, ille, итд. [...] Безлични глаголи су такви који се уопште користе само у трећем лицу једнине." (ШипЕР 1832: 28; 84; превод наш - Б. С.).

${ }^{2}$ На ову особину традиционалне граматике указује проф. Љ. Поповић (предавања).

${ }^{3}$ Приручнике дајемо оним редом којим су се појављивали у првом издању. Све цитате у табели дајемо на ћирилици, без обзира којим су писмом изворно штампани. Изостављамо евентуално обележене акценте. Истицања су изворна. 


\begin{tabular}{|c|c|}
\hline ЛАЛЕВИЋ 1962 & $\begin{array}{l}{[\Pi] \text { рава имперсоналија [су] такви глаголи код којих се }} \\
\text { наместо es [у Es regnet = Kuши на нем.] не може замис- } \\
\text { лити никакав одређен субјекат. Стога је било предлога } \\
\text { да се такви глаголи зову бесубјектни, јер је то прилич- } \\
\text { није него безлични: глагол тако употребљен има личну } \\
\text { форму, одређен лични облик (треће лице) иако нема } \\
\text { лица на које се односи, [...] али лице као покретач радње } \\
\text { није одређено. (173) }\end{array}$ \\
\hline СТЕВАНОВИТ ${ }^{4} 1989$ & [Нема јасног одређења.] \\
\hline $\begin{array}{l}\text { ПЕЦО/СТАНОЈЧИЋ } \\
\text { (ред. и ур.) } 1972\end{array}$ & $\begin{array}{l}\text { БЕЗЛИЧНИ (ИМПЕРСОНАЛНИ) ГЛАГОЛИ, глаго- } \\
\text { ли који се употребљавају у безличном смислу, који не } \\
\text { указују на лице као на вршиоца одн. покретача глагол- } \\
\text { ске радње (активности) или збивања, одн. на носиоца } \\
\text { неког стања. Безлични глаголи употребљавају се само } \\
\text { у облику 3. л. јд. средњега рода. Такви су нпр. глаголи: } \\
\text { грмети (Грми.), севати (Сева.), свитати (Свиће.), ки- } \\
\text { шити (Киши.), снежити (Снежи.) [...] } \\
\text { БЕЗЛИЧНИ ПОВРАТНИ ГЛАГОЛИ [...] су најчешће } \\
\text { глаголи који показују неко збивање у природи, али се } \\
\text { не може тачно рећи чему се то збивање приписује, као } \\
\text { нпр. облачити се, разведравати се, смркавати се, раз- } \\
\text { дањивати се и сл., затим глаголи типа дешавати се, до- } \\
\text { гађати се и сл., чија се радња не приписује одређеном } \\
\text { граматичком лицу. }\end{array}$ \\
\hline КАтичић 1986 & 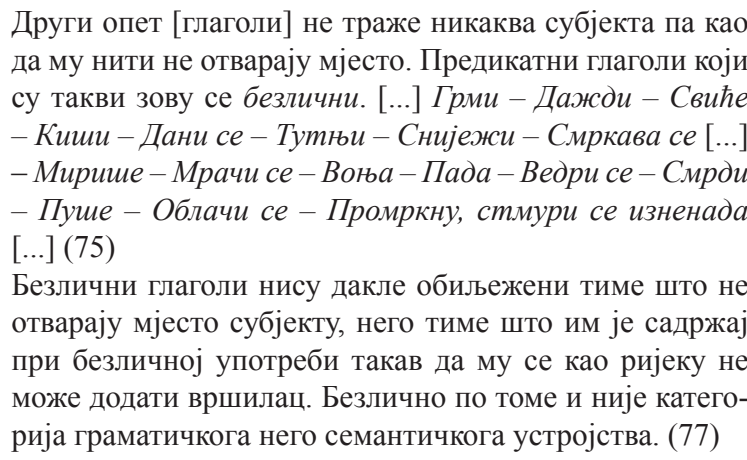 \\
\hline Миновић 1987 & $\begin{array}{l}\text { [У] неким оваквим [= безличним] реченицама налазе се } \\
\text { бе з л и ч и г глагол и, тј. глаголи који у својој семан- } \\
\text { тици не подразумијевају различита лица (граматичка) } \\
\text { као вршиоце радње или сл., већ се употребљавају у } 3 . \\
\text { лицу једнине (нпр. грмјети, сијевати и сл.). (65) }\end{array}$ \\
\hline
\end{tabular}




\begin{tabular}{|c|c|}
\hline Поповић ${ }^{13} 2011$ & $\begin{array}{l}\text { [Безлични глаголи су они] којим се исказују - или се } \\
\text { могу исказати - неприписане ситуације; такви су гла- } \\
\text { голи: свањивати, сванути, смркавати се, смрћи се, } \\
\text { смрачити се, севати, грмети, дувати, пљуштати, на- } \\
\text { облачити се, разведрити се, отоплити, захладнети и } \\
\text { сл. (многи ови глаголи могу бити и лични, одн. персо- } \\
\text { нални [...]. (261) } \\
\text { [Безлични глаголи су они] који не подразумевају пос- } \\
\text { тојање неког носиоца ситуације. (265) }\end{array}$ \\
\hline МРАЗОВИЋ ${ }^{2} 2009$ & $\begin{array}{c}\text { [„Безлични глаголи” наводе се само у регистру, али у } \\
\text { оним одељцима на које се из регистра упућује - } \\
\text { овог термина нема.] }\end{array}$ \\
\hline БАРИЋ et al. ${ }^{2} 1997$ & $\begin{array}{l}\text { Глаголи који по својем значењу долазе само у } 3 \text {. лицу, } \\
\text { али без субјекта, називају се безличним глаголима. } \\
\text { То су глаголи збивања и стања која асе односе на жива } \\
\text { бића и природне појаве уопће: чинити се, позлити; } \\
\text { снијежити, смркавати се, грмјети [...]. } \\
\text { Безлични су и глаголи као болети, зелељети се, који се } \\
\text { повезују са субјектом, али опет само у } 3 \text {. лицу: боли ме } \\
\text { глава, трава се зелени итд. (229) } \\
\text { Предикатни глаголи који не отварају мјесто никакву } \\
\text { субјекту зову се безлични глаголи. (427) }\end{array}$ \\
\hline $\begin{array}{l}\text { СИЛИЋ/ПРАњКОВИЋ } \\
{ }^{2} 2007\end{array}$ & [Нема јасног одређења.] \\
\hline ПИПЕР 2005 & $\begin{array}{l}\text { [Безлични глаголи су они који] у својој парадигми } \\
\text { имају само облике трећег лица једнине и средњег рода } \\
\text { (код облика који имају и лице и род), и }[\ldots] \text { означавају } \\
\text { процесе или стања узете независно од њиховог узроч- } \\
\text { ника или носиоца, нпр. [...] У соби се почело мрачити. } \\
{[\ldots] \text { Смркава се. }[\ldots] \text { Позлило јој је. }} \\
\text { Ограничено-лични глаголи [имају исте те особине, али] } \\
\text { могу означавати процесе или стања чији је носилац } \\
\text { именован }[\ldots] . \text { Свиће. }[\ldots] \text { Зора свиће. }[\ldots] \text { Грми. [...] } \\
\text { Гром загрме на светог Илију. (603) }\end{array}$ \\
\hline ПИПЕР/КЛАЈН ${ }^{2} 2014$ & $\begin{array}{c}\text { [Слично као у Пипер 2005, с тим што се не помињу } \\
\text { „ограничено-лични” глаголи, већ се и такви називају } \\
\text { безличним.] }\end{array}$ \\
\hline
\end{tabular}

\section{Табела 1}

Као што видимо, у једном приручнику се безлични глаголи уопште не помињу (МАРЕтић $\left.{ }^{3} 1963\right)$, у два се не може наћи цитат у коме се на јасан начин дефинишу или одређују (СтевАНОвић ${ }^{4} 1989$, Силић/ПрањКовић $\left.{ }^{2} 2007\right)$, а у једном је, рекло би се, уложен чак и свестан напор да се овај термин и појам избегне (МРАзовић $\left.{ }^{2} 2009\right)$. А. Белић употребљава термин глАГоли ЗА БиВАњЕ, 
док П. Пипер (2005) уводи термин огрАничЕно-лични глаголи за оне безличне глаголе који се могу употребити и као лични (с тим што није до краја јасно зашто такви не би били и глаголи мрачити се (уп. Небо се мрачило) и смркавати се (уп. Небо се смркавало)). Поменућемо и да бар један приручник безличним глаголима, очигледно, сматра и личне глаголе у обезличеној реченици (УП. Говори се у примеру из БРАБЕц et al. ${ }^{2} 1954$ ).

2.3. Уз опаску да вероватно није свим ауторима био циљ да дају најпрецизнију могућу дефиницију, па можда ни да дају дефиницију уопште, већ да појаву представе на најприкладнији начин, оно што ипак можемо из овог прегледа закључити јесте да се користе, и обично међусобно комбинују, критеријуми које можемо грубо сврстати у три врсте.

Првим критеријумом, сЕмАнтичким, истиче се да безлични глаголи означавају ситуацију чији се носилац (одн. „покретач”, „вршилац”, „узрочник”) „не зна, „не може замислити”, „не може одредити”, или се на њега „не указује”, односно ситуацију „узету независно” од носиоца, ситуацију за коју се носилац „не подразумева”, ситуацију која је „неприписана”.

Другим критеријумом, синтАКсичким, има се у виду структурни састав реченице коју безлични глаголи граде: они „не траже” субјекат, „не отварају му место”, па у таквим реченицама субјекта „не може ни бити”. Синтаксичким, одн. семантичко-синтаксичким, може се сматрати и одређење ситуације као „неприписане”, будући да то приписивање има обавезно свој формално-синтаксички одраз у конгруенцији предиката с граматичким субјектом.

Трећи критеријум, моРФолошки, примењује се у две варијанте, које можемо назвати ,јака” и „слаба”. Прва узима да глагол у својој парадигми уопште и нема облике за сва три лица, већ само за 3. л. (јд., ср. p.), чиме се практично дефиниција премешта на терен морфологије, а безлични глаголи сврставају међу глаголе с дефектном парадигмом. Ако се пак каже да се безлични глагол „не употребљава” у другим лицима осим у трећем (што је други случај, одн. „слаба” формулација), тиме се ипак допушта да глагол има облике за остала лица, али по природи ствари, услед специфичности означене ситуације одн. глаголске семантике - за њима неће никад бити потребе, јер се ситуација никада не приписује ни говорнику ни саговорнику. На овом месту можемо додати да се ,јаки” морфолошки критеријум за дефинисање безличних глагола и њихово разликовање од личних користи и у референтном граматичком приручнику чешког језика (ГРЕпл et al. 1987: 159-160); слично поступа и академијина граматика руског језика, но ипак додаје да међу личним глаголима нема мало оних који се не користе у 1. и 2. лицу (ШведовА (гл. ред.) 1980: 582). А ако се ,јаки” морфолошки критеријум, одн. дефектност парадигме, узима као основ, онда се понекад даје предност терминима монопЕРСонАлни ОДН. УНИПЕРСОНАЛНИ (ГЛАГОЛ) (УП. СИМЕОН 1969, као и КАРЛСОН 2000).

Ове три врсте критеријума у доброј мери одражавају и различите приступе феномену безличности уопште, не само у домаћој граматографији, већ и у типолошкој и општетеоријској литератури. Како примећује А. Сјевјерска, ту семантичка карактеризација има обично једно од два упоришта: прво је утврђивање непостојања особног, тј. људског агенса (ма како се он 
схватао) који би био контролор ситуације - такве конструкције типично означавају метеоролошке феномене, затим телесне осећаје и емоције, као и модал(изова)не ситуације; друго упориште је утврђивање (не)референтности одн. (не)специфичности ентитета који је покретач ситуације. Синтаксичка пак карактеризација безличности укључује „бесубјектност”: (граматички) субјекат или уопште не постоји, или је плеонастичан одн. семантички празан, било као „откривен” (енгл. overt), било „скривен” (енгл. covert). Коначно, из морфолошке перспективе безличност се легитимише тиме што је „главни” глагол употребљен тако да или не спецификује лице уопште, или се налази обавезно у облику трећег лица (СЈЕВЈЕРскА 2008).

Ове различите перспективе не морају увек искључивати једна другу, али могу довести граматичара у незгодан положај ако треба да се определи за важнију (уп. нпр. цитат из КАтичић 1986), па и ставити га у ситуацију да формулише контрадикторну дефиницију, која би требало да примени и синтаксички (,бесубјектност”) и морфолошки критеријум (,блокираност трећег лица") - као у БАрић et al. ${ }^{2} 1997$. Они се, наиме, тешко могу помирити.

3. Пре но што покушамо понудити задовољавајуће решење, осврнућемо се накратко на то како су безлични глаголи препознати и третирани у домаћој лексикографској пракси. У Речнику српскога језика Матице српске (РСЛ) квалификатор „безл.” (= „безлично”) употребљен је двестотинак пута. ${ }^{4}$ Осим глагола где би се овај квалификатор свакако и очекивао, какви су сванути, гpмети, позлити и сл., срећемо га и на другим местима. Уп. следеће цитате: ${ }^{5}$

болети јек. бољети, боли несвр. безл. 1. бити обузет болом, одавати бол, бити извор бола. - Боли ме глава. 2. (некога) осећати бол, имати бол (болове). — Боли ме у грлу. 3. причињавати, задавати бол. - Боле ме убоди. фиг. Неправда ме боли. [...]

десити се, десим се свр. 1. ( ․ л. гл. времена) догодити се, збити се (нпр. о неком догађају). [...]

догодити се, -им се свр. десити се, збити се (обично изненада, одједном). - Нешто им се сигурно догодило.

писати, пишем несвр. (нешто) 1. служити се оловком, бележити. 2. састављати какав текст (књижевно, научно или др. дело). [...] 4. безл. налазити се написано, одштампано. - Пише то у књигама. [...]

предстојати, -ји свр. безл. налазити се пред неким (о нечему што ће се догодити), бити очекиван у будућности. - Предстоји нам много рада.

прећи (прећи), пређем [...] свр. 1. идући, премештајући се превалити (какво растојање, какав простор): земљу банатску, мост, улицу, ограду, пет километара за сат. [...] 8. безл. (са лог. субјектом у акуз.) престати осећати нешто непријатно, превазићи бол, страх и сл. - Прешла ме је нога. Прешао ме је страх. [...]

присести [...] свр. 1. сести на кратко време, мало поседети. - Док се оне пентрају по дрветима, ја приседнем на клупу. [...] 3. (безл.) а. застати, запети у грлу, једњаку, засести (о залогају). - Присео му је од страха залогај у грлу. б. безл. (са лог. субјектом у дативу) фиг. осетити непријатност, нерасположење због нечега. - Присело ми је све што сам међу њима рекао.

${ }^{4}$ Међутим, то не значи безличних глагола у речнику има толико, пошто је, с једне стране, овај квалификатор коришћен и за сваку другу врсту употребе која је оцењена „безличном” (укључујући и обезличене реченице), а с друге стране, имперфектив(изова)ни глаголски парњаци, безлични или не, по правилу су давани без икаквог квалификатора, него само с граматичком дефиницијом облика „,несвр. према $X$ '.

${ }^{5}$ Цитате дајемо без акцената. Квалификаторе од значаја смо подвукли. 
сврбети [...] несвр. имати неоугодан осећаја голиц̧ања и пец̧кања на кожи; уп. свраб (2) и сврбеж. [...]

сладити, сладим несвр. [...] $\sim$ се 1. јести или пити с уживањем, осећајући сласт: $\sim$ се крушком, $\sim$ и вином. [...] 3. безл. годити, пријати, милити се. - Сладио му се такав живот.

На први поглед, могло би се помислити да се лексикограф држао морфолошког критеријума, с обзиром на то да су као безлични квалификовани глаголи болети (и то у оба своја значења - под 1, с граматичким субјектом, и под 2 , без њега) и предстојати, као и глаголи писати, присести, прећи и сладити се, у оним значењима у којима се употребљавају само у 3 . л., опет без обзира на то што имају уз себе граматички субјекат у номинативу, који је видљив и у примерима. Безлични квалификатор, међутим, није добио глагол сврбети, који је и по значењу, и по облику у ком се употребљава, и по саставу реченице коју гради - врло сличан глаголу болети. Глагол десити се (у значењу под 1) не добија такав квалификатор иако задовољава морфолошку дефиницију безличности, већ уз њега стоји „у 3. л. гл. времена”, а да конфузија буде већа, његов синоним догодити се није добио ни овакво одређење. Таквих случајева могли бисмо навести још, али није нам циљ да лексикографа излажемо критици, већ да покажемо да је овај квалификатор (односно теоријски појам) примењиван проблематично и недоследно, што свакако може бити одраз његовог некохерентног теоријског третмана ван лексикографије.

4. Важно је истаћи да овде не разматрамо која је и каква дефиниција безличног глагола „тачна”, а која „погрешна”, већ да ли се може изнаћи дефиниција која је, прво, једноставна, друго - употребљива, и треће - таква да ће дати појам који је релевантан за синтаксу. Први услов подразумева да би било пожељно одабрати само један критеријум, ако је то могуће, и формулисати га што једноставније. Други услов подразумева да дефиниција треба да буде таква да је свако - и лингвиста и наставник у школи - може лако применити, и без напора и недоумице за дати глагол (у датој реченици) проценити да ли је безличан, односно безлично употребљен. Тај услов тешко да може задовољити дефиниција која се служи семантичким критеријумима, с обзиром да се и појам као што је „вршилац” одн. „агенс” (чије би постојање одн. непостојање требало утврђивати) данас сматра пре дифузном него дискретном семантичком категоријом (уп. нпр. Даути 1991, као и Стипчевић 2008). Што се тиче морфолошки утемељене дефиниције, она би могла, да поновимо, формуЛИсати бИЛо у ,јакој” (БЕЗЛИЧАН ГЛАГОЛ ЈЕ ОНАЈ КОЈИ ИМА САМО ОБЛИК 3. ЛИЦА), биЛО У „СЛабој” варијанТИ (БЕЗЛИЧАН ГЛАГОЛ ЈЕ ОНАЈ КОЈИ СЕ УПОТРЕБљАВА САмо у облику 3. лицА). Обе нам се чине проблематичне. Наиме, разумно је претпоставити да различити говорници (тј. и они који граматику пишу, и они који је користе у научне, стручне и школске сврхе) могу имати различит суд о томе да ли глагол „има” или „нема” облике 1. и 2. лица, а мора се добро водити рачуна и о томе да оно што је могуће у језику не кореспондира увек и нужно с оним што је могуће у стварности. ${ }^{6}$ Додатну тешкоћу причињава и

${ }^{6}$ Да такав суд није тривијалан, показује и куриозитет какав налазимо у шестотомном Речнику Матице српске (РМC), где је, за разлику од свих других придева, лексикограф лексему тру- 
чињеница да има изузетно мало глагола који се не могу употребити никако другачије него као безлични (ма који критеријум имали у виду): такве глаголе могли бисмо звати АПсолутно БЕзлични глАголи ${ }^{7}$ и прелиминарна анализа на $P C J$ показује да би их у српском језику могло бити тек неколико десетина. Сви остали су или примарно безлични, с тим да допуштају и личну употребу, или су примарно лични, с тим да могу бити безлично употребљени. Дакле, искључиво морфолошки утемељена дефиниција тешко да би била нарочито ПрименљИва И У овим сЛУчајевИМа (УП. БЕЗЛИЧНО УПОТРЕБљЕН ГЛАГОЛ ЈЕСТЕ ОНАЈ КОЈИ ЈЕ УПОТРЕБљЕН КАО ДА ИМА САМО ОБЛИК 3. ЛИЦА, ОДНОСНО ...КАО ДА СЕ УПОТРЕБљАВА САМО У ОБЛИКУ 3. ЛИЦА).

Трећи услов који смо поменули - релевантност - почива на захтеву да појам који се превасходно користи у синтакси (о чему довољно говори чињеница да се у свим домаћим граматичким приручницима о безличним глаголима говори у поглављу о синтакси, а не о морфологији) треба да буде дефинисан тако да омогући да се различите синтаксичке законитости лакше, једноставније и елегантније опишу и представе. Покушаћемо да илуструјемо шта имамо у виду.

Глаголи као што су сванути и свитати задовољавају било који од поменутих критеријума за безличност. За разлику од личних глагола, њихове употребне могућности знатно су сужене: познато је да се не могу употребити у императиву, одн. градити заповедне реченице за директну заповест (бар не ван метафоричке личне употребе); није им доступан ни рефлексивни ни партиципски пасив, па ни „безлични” партиципски пасив, који иначе могу имати многи непрелазни лични глаголи (На ґих је пуц̧ано). Инфинитив глагола сванути и свитати практично нема никакву синтаксичку функцију осим грађења допунског дела сложеног предиката, док инфинитиви (и инфинитивне синтагме) других глагола имају много ширу употребу (уп. Лепо је рано устати, али *Лепо је рано сванути; делиберативно Када устати?, али *Када сванути? и сл. $)^{8}$. Много ређе се пак има у виду чињеница да се глаголи као што су сванути и свитати не могу у клаузи употребити у облику глаголског прилога, ни садашњег ни прошлог ( ${ }^{*}$ Сванувши, изашли смо напоље $)^{9}$, а још peђе се помиње да клауза с овим глаголима у предикату не може садржати гл. прилог садашњи ни прошли (било сам, било као центар гл. синтагме) неког другог глагола (уп. * Враћајући се кући, свануло је, "Дошавши кући, свануло je). Ова листа особености вероватно није коначна, и вероватно се свака од њих може објаснити из различитих углова, али један од елегантних начина да ове особености објединимо, а уједно и предвидимо синтаксичко понашање

дан дао искључиво у облику женског рода (трудна), проглашавајући облике мушког и средњег рода непостојећим. На тај начин је изгубио из вида да језик служи и да саопштавамо о стварима које не постоје (нпр. Мушкарац не може бити трудан), као и да граматички род и природни пол нису увек у сагласности (Девојчурак је трудан, Девојче је трудно). Захваљујемо проф. др Душку Витасу што нам је скренуо пажњу на овај детаљ.

${ }^{7}$ Термин АПСолутно БЕзлични глАгол у овом значењу предложио је Л. Баби (1989).

${ }^{8}$ М. Ивић (1972) детаљније описује репертоар синтаксичких употреба инфинитива у српском језику.

${ }^{9}$ На ову околност, али у руском језику, скреће нарочито скреће пажњу Л. Баби (1975). 
других глагола, јесте да их доведемо у везу управо с појмом безличности - али дефинисаном не морфолошки, него синтаксички! Наиме, неки други глаголи, као што су болети, сврбети, дешавати се и сл., који задовољавају поменуту морфолошку дефиницију (јер су увек у 3. л.), али не синтаксичку (jер се користе с граматичким субјектом) - не показују истоветно понашање када су посреди њихови глаголски прилози (уп. Рука ми је отицала, болећи ме све више, Рука ме је болела, отичући све више; Крађе су се дешавале свакодневно, стварајући напету атмосферу, Дешавајући се свакодневно, крађе су стварале напету атмосферу и сл.). Другим речима, синтаксичка дефиниција безличних глагола резултује нешто оскуднијим њиховим инвентаром, али се такав инвентар чини боље заокружен и синтаксички релевантан.

На основу свега досад изложеног, мислимо да има добрих разлога да синтаксичкој дефиницији одлучно дамо предност. Покушаћемо сада да је разрадимо и додатно прокоментаришемо.

5. Поновићемо предложену синтаксичку дефиницију безличног глагола: БЕЗЛИЧНИ ГЛАГОЛИ СУ ОНИ КОЈИ НЕ ЗАХТЕВАЈУ ГРАМАТИЧКИ СУБЈЕКАТ ДА БИ ФОРМИРАЛИ ПРЕДИКАТСКУ РЕЧЕНИЦУ .

Оваква дефиниција ослања се на раније синтаксичке дефиниције (КАтичић 1986, Поповић $\left.{ }^{13} 2011\right)$. Мислимо да је важно да дефиниција садржи као кључан елеменат баш граматички субјекат (а не „носиоца ситуације”), пошто се ради о добро дефинисаном и лако препознатљивом конституенту. У супротном, глаголи као што је позлити, који не захтева граматички субјекат, већ логички субјекат у дативу - за који се и даље може рећи да означава носиоца ситуације - остали би изван скупа безличних глагола. Оваква дефиниција уважава „вербоцентричну” перспективу у синтаксичкој анализи, коју, у различитим видовима, већина савремених синтаксичких теорија узима као полазишну, а подразумева да је предикатски глагол централни и најважнији реченични члан: његова синтаксичко-семантичка својства диктирају присуство (или одсуство) других реченичних чланова, који се отуд сматрају његовим аргументима одн. допунама; сви заједно тако чине минималну структуру, која се може проширивати необавезним, одредбеним конституентима. Према томе, ако глагол не захтева граматички субјекат, а то је типично номинал у номинативу, субјекта у реченици неће - и не може - бити. Стога би алтернативни термин за безличне глаголе могао бити БЕсуБЈЕКАТски глаголи, за шта је и раније било предлога у литератури (в. т. 2.2). Веза између предиката и граматичког субјекта има и своје формално обележје, а то је конгруенција. Ако је глагол такав да не захтева граматички субјекат, онда он неће имати са чим да конгруира, па ће стајати у најнеутралнијем могућем финитном облику (могло би се рећи и „предефинисаном”, енгл. default), а то је 3. л. јд. (ср. р.). Дакле, овде је важно приметити да овако постављена дефиниција безличног глагола подразумева да је његов (неутрални) облик - последица безличности, а не предуслов за њу! Треба, такође, имати у виду да се граматички субјекат у датој реченици може и подразумевати, тј. бити неизречен - тада се обично говори о нултом суБЈекту, који и даље, међутим, функционише као контролор конгруенције; да бисмо за предикат такве реченице проценили да 
ли је реализован личним или безличним глаголом, довољно је да утврдимо да ли је у конгруентном или неутралном облику, односно да покушамо у реченицу „вратити” подразумевани субјекат. Осим номиналом у номинативу (Свиђа ми се ова песма), граматички субјекат може бити реализован и мање типичним синтаксичким јединицама: партитивном синтагмом формираном од прилошке речи (Свиђа ми се неколико песама), неким врстама зависних клауза (Свиђа ми се да певам / шито волиш да певаш), па и инфинитивном јединицом (Свиђа ми се певати наглас); и такве јединице сматрамо граматичким субјектом, зато што су и даље заменљиве номиналом у номинативу. Но, како саме нису у номинативу (нити у било ком падежу, јер су лишене падежне категорије), оне не могу бити контролор конгруенције, па ће предикат с таквим субјектима опет стајати у неутралном, инконгруентном финитном облику. Али, ако се држимо постављене дефиниције, такав глагол нећемо сматрати безличним, па ни безлично употребљеним: његов неутрални облик условљен је нарочитом реализационом варијантом субјекта, а не чињеницом да он субјекат уопште не захтева. Слично би важило и за различите примере с тзв. генитивним суьЈектом. О тим случајевима, као и даљим консеквенцама овакве концепције, могућој колизији с другим концепцијама (нпр. оној о „слободној” и „везаној” безличности у Ивић 1963) - намеравамо детаљније говорити другом приликом.

\section{ЛИТЕРАТУРА}

Барић et al. ${ }^{2}$ 1997: Eugenija Barić, Mijo Lončarić, Dragica Malić, Slavko Pavešić, Mirko Peti, Vesna Zečević, Marija Znika, Hrvatska gramatika, II. promijenjeno izdanje, Zagreb: Školska knjiga.

Баби 1975: Leonard H. Babby, „Impersonal verbs and their lexical specification”, The Slavic and East European Journal, 19/2, 182-187.

Баби 1989: Leonard H. Babby, ,Subjectlessness, external cubcategorization, and the Projection Principle", Зборник Матице српске за филологију и лингвистику, XXXII/2, 7-40.

Белић 1933/2000: А. Белић, Граматика српскохрватског језика за трећи разред средюих и стручних школа, Београд: Издавачка књижарница Геце Кона, 1933 [Прештампано у: Александар Белић, Граматике. О граматикама (приредила Даринка Гортан-Премк), Београд: Завод за уџбенике и наставна средства, 2000, 179-273].

Брабец et al. ${ }^{2}$ 1954: Ivan Brabec, Mate Hraste, Sreten Živković, Gramatika hrvatskoga ili srpskog jezika (II prerađeno i nadopunjeno izdanje), Zagreb: Školska knjiga.

Грепл et al. 1987: Miroslav Grepl, František Daneš, Zdeněk Hlavsa, Mluvnice češtiny 3. Skladba, Praha: Academia.

Даути 1991: David Dowty, „Thematic proto-roles and argument selection”, Language, 67/3, 547-619. 
Ивић 1963: Milka Ivić, „Osnovne tipološke karakteristike srpskohrvatske impersonalne rečenice", Книжевност и језик, X/1, 18-24.

Ивић 1972: Milka Ivić, „Problematika srpskohrvatskog infinitiva”, Зборник Матице српске за филологију и лингвистику, XV/2, 115-138.

Караџић 1814: Вук Стефановић Караџић, Писменица сербскога іезика по говору простога народа, Беч.

Караџић 1818: Вук Стефановић Караџић, Српски рјечник, истолкован њемачким и латинским ријечма, Беч.

Карлсон 2000: Fred Karlsson, „Defectivity”, [у књизи] G. E. Booij, Christian Lehmann, Joachim Mugdan (Eds.), Morphologie: ein internationales Handbuch zur Flexion und Wortbildung = Morphology: an international handbook on inflection and word-formation. Berlin: Mouton de Gruyter, 647-654.

Катичић 1986: Radoslav Katičić, Sintaksa hrvatskoga književnog jezika: nacrt za gramatiku, Zagreb: JAZU-GLOBUS.

Лалевић 1962: Миодраг С. Лалевић, Синтакса српскохрватскога књижевног језика, Београд: Завод за издавање уџбеника Народне Републике Србије.

Маретић ${ }^{3}$ 1963: Tomo Maretić, Gramatika hrvatskoga ili srpskoga književnog jezika (3., nepromijenjeno izdanje), Zagreb: Matica hrvatska.

Миновић 1987: Milivoje Minović, Sintaksa srpskohrvatskog - hrvatskosrpskog književnog jezika za više škole. Rečenica, padeži, glagoli, Sarajevo: Svjetlost - Zavod za udžbenike i nastavna sredstva.

Мразовић[/Вукадиновић] 22009: Pavica Mrazović, u saradnji sa Zorom Vukadinović, Gramatika srpskog jezika za strance, drugo, prerađeno i dopunjeno izdanje, Sremski Karlovci - Novi Sad: Izdavačka knjižarnica Zorana Stojanovića.

Пецо/Станојчић (ред. и ур.) 1972: Asim Peco, Živojin Stanojčić (red. i ur.), Enciklopedijski leksikon - Mozaik znanja: Srpskohrvatski jezik, Beograd: Interpres, 1972.

Пипер 2005: Предраг Пипер, „Семантичке категорије у простој реченици: синтаксичка семантика”, [у књизи] Предраг Пипер, Ивана Антонић, Владислава Ружић, Срето Танасић, Људмила Поповић, Бранко Тошовић, Синтакса савременога српског језика (проста реченииа), БеоградНови Сад: Институт за српски језик САНУ - Матица српска, 575-982.

Пипер/Клајн 22014: Предраг Пипер, Иван Клајн, Нормативна граматика српског језика, друго, измењено и допуњено издање, Нови Сад: Матица српска.

Поповић ${ }^{132011: ~ Љ у б о м и р ~ П о п о в и ћ, ~ „ С и н т а к с а ”, ~[у ~ к њ и з и] ~ Ж и в о ј и н ~ С т а-~}$ нојчић, Љубомир Поповић, Граматика српског језика за гимназије и средње школе, Београд: Завод за уџбенике, 206-386.

PMC: Речник српскохрватскога књижевног језика, I-VI, Нови Сад (- Загреб): Матица српска (- Матица хрватска), 1967-1976.

PCJ: Речник српскога језика, измењено и поправљено издање, Нови Сад: Матица српска, 2011.

Силић/Прањковић 22007: Josip Silić, Ivo Pranjković, Gramatika hrvatskoga jezika (za gimnazije $i$ visoka učilišta), 2. izdanje, Zagreb: Školska knjiga. 
Симеон 1969: Rikard Simeon, Enciklopedijski rječnik lingvističkih naziva I-II, Zagreb: Matica hrvatska.

Сјевјерска 2008: Anna Siewierska, „Ways of impersonalizing: pronominal vs verbal strategies", [у књизи] G. González, M. d. 1. Ángeles, J. L. Mackenzie, E. M. González (Eds.), Current Trends in Contrastive Linguistics: Functional and Cognitive Perspectives, Amsterdam: John Benjamins, 3-26.

Стевановић ${ }^{4}$ 1989: Михаило Стевановић, Савремени српскохрватски језик (граматички системи и књижевнојезичка норма) II. Синтакса (четврто издање), Београд: Научна књига.

Стевовић 1960: Игрутин Стевовић, Функиионална граматика српскохрватског језика. Основи, [Београд:] Завод за издавање уџбеника Народне Републике Србије.

Стипчевић 2008: Балша Стипчевић, „Семантичке улоге у савременој лингвистичкој теорији”, Научни састанак слависта у Вукове дане, 36/3, $115-154$.

Шведова (гл. ред.) 1980: Н. Ю. Шведова (гл. ред.), Русская грамматика I, Москва: Наука.

Шипер 1832: Benedict Schipper, A concise and comprehensive practical grammar of the Latin tongue. Philadelphia: Mifflin \& Parry.

Balša N. Stipčević

WHAT ARE IMPERSONAL VERBS?

\section{Summary}

The author examines the concept of impersonal verbs in grammatical literature, taking also into account their lexicographic treatment. The criteria for their definition are analyzed and discussed. 